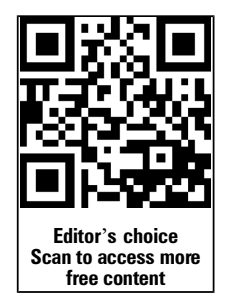

- Additional material is published online only. To view please visit the journal online (http://dx.doi.org/10.1136/ oemed-2014-102534).

For numbered affiliations see end of article.

\section{Correspondence to} Dr S Jill Stocks, Centre for Occupational and

Environmental Health, 4th Floor Ellen Wilkinson Building, University of Manchester, Oxford Rd, Manchester, M13 9PL, UK; jill.stocks@ manchester.ac.uk

Received 26 August 2014 Revised 28 November 2014 Accepted 14 December 2014 Published Online First 9 January 2015

\section{CrossMark}

To cite: Stocks SJ, McNamee $R$, van der Molen HF, et al. Occup Environ Med 2015;72:294303

\title{
Trends in incidence of occupational asthma, contact dermatitis, noise-induced hearing loss, carpal tunnel syndrome and upper limb musculoskeletal disorders in European countries from 2000 to 2012
}

S Jill Stocks, ${ }^{1,2}$ Roseanne McNamee, ${ }^{3}$ Henk F van der Molen, ${ }^{4}$ Christophe Paris, ${ }^{5,6}$ Pavel Urban, ${ }^{7,8}$ Giuseppe Campo, ${ }^{9}$ Riitta Sauni, ${ }^{10}$ Begoña Martínez Jarreta, ${ }^{11}$ Madeleine Valenty, ${ }^{12}$ Lode Godderis, ${ }^{13,14}$ David Miedinger, ${ }^{15,16}$ Pascal Jacquetin, $^{17}$ Hans M Gravseth, ${ }^{18}$ Vincent Bonneterre, ${ }^{19}$ Maylis Telle-Lamberton, ${ }^{20}$ Lynda Bensefa-Colas, ${ }^{21,22}$ Serge Faye, ${ }^{23}$ Godewina Mylle, ${ }^{14}$ Axel Wannag, ${ }^{24}$ Yogindra Samant, ${ }^{24}$ Teake Pal, ${ }^{4}$ Stefan Scholz-Odermatt, ${ }^{15,25}$ Adriano Papale, ${ }^{9}$ Martijn Schouteden, ${ }^{14}$ Claudio Colosio, ${ }^{26}$ Stefano Mattioli, ${ }^{27}$ Raymond Agius, ${ }^{1}$ Working Group 2; Cost Action IS1002-Monitoring trends in Occupational Diseases and tracing new and Emerging Risks in a NETwork (MODERNET)

\section{ABSTRACT}

Objectives The European Union (EU) strategy for health and safety at work underlines the need to reduce the incidence of occupational diseases (OD), but European statistics to evaluate this common goal are scarce. We aim to estimate and compare changes in incidence over time for occupational asthma, contact dermatitis, noise-induced hearing loss (NIHL), carpal tunnel syndrome (CTS) and upper limb musculoskeletal disorders across 10 European countries.

Methods OD surveillance systems that potentially reflected nationally representative trends in incidence within Belgium, the Czech Republic, Finland, France, Italy, the Netherlands, Norway, Spain, Switzerland and the UK provided data. Case counts were analysed using a negative binomial regression model with year as the main covariate. Many systems collected data from networks of 'centres', requiring the use of a multilevel negative binomial model. Some models made allowance for changes in compensation or reporting rules.

Results Reports of contact dermatitis and asthma, conditions with shorter time between exposure to causal substances and $\mathrm{OD}$, were consistently declining with only a few exceptions. For OD with physical causal exposures there was more variation between countries. Reported NIHL was increasing in Belgium, Spain, Switzerland and the Netherlands and decreasing elsewhere. Trends in CTS and upper limb musculoskeletal disorders varied widely within and between countries.

Conclusions This is the first direct comparison of trends in OD within Europe and is consistent with a positive impact of European initiatives addressing exposures relevant to asthma and contact dermatitis. Taking a more flexible approach allowed comparisons of surveillance data between and within countries without harmonisation of data collection methods.

\section{What this paper adds}

- Improving collection and analysis of data to measure trends in occupational diseases has long been, and continues to be, a strategic aim of past and future European Union strategies for health and safety at work.

- Statistics to compare changes in incidence in occupational diseases between European countries are scarce.

- For the first time we have compared trends in incidence of occupational dermatitis, asthma, noise-induced hearing loss, carpal tunnel syndrome and upper limb musculoskeletal disorders between European countries.

- Reports of contact dermatitis and asthma were declining within most countries, consistent with a positive impact of European initiatives addressing the relevant exposures.

- Taking a more flexible approach by allowing each country to provide data that is relevant to their individual occupational healthcare systems does not rule out international epidemiological studies.

\section{INTRODUCTION}

The European Union (EU) strategy for health and safety at work 2007-2012 underlines the need to reduce the incidence of occupational diseases (ODs). ${ }^{1}$ In 2003, the European Agency for Safety and Health at Work stated that "no single data source can provide a complete and adequate description of occupational safety and health". ${ }^{2}$ Furthermore, the evaluation of the above European strategy in 2013 concluded that little progress has been made with regard to harmonising statistical 
methods for collecting and processing data on OD. ${ }^{3}$ Previously, the statistical office of the EU (Eurostat) ${ }^{4}$ offered two databases on occupational health and safety: European Statistics on Accidents at Work ${ }^{5}$ and European OD Statistics. ${ }^{6}$ However, following a decision by the Health and Safety at Work Statistics Working Group, European OD Statistics have not been collected since 2009 (personal communication). It was said that the large variation in the data quality made it unreliable for cross-country comparisons. There are large variations between countries for self-reported work-related accidents and health problems, which may, at least in part, reflect variation in attitudes to reporting. For example, in 2007, 24.5\% of Finnish respondents reported one or more work-related health problems in the past 12 months compared with 3\% for Irish respondents. ${ }^{7}$

Given differences between the OD surveillance systems in each country-including differences in coverage and 'capture' of cases of occupational ill health-determination of true incidence and comparisons of incidence between countries may be problematic, but measures of change in incidence over time within countries may not be affected by many of these problems. Such estimates of changes over time within a system have been published, for example, in France, ${ }^{8}$ Belgium $^{9}$ and the UK. ${ }^{10}$ Furthermore, these rates of change in incidence may be comparable between countries provided due consideration is given to changes in the population at risk over time, changes in the methods of data collection over time and any other temporal factors unrelated to true changes in incidence. ${ }^{10}$

MODERNET is an EU wide network aiming to develop new methods to estimate incidence and trends in OD and identify new and emerging risks; working group 2 of MODERNET focuses on methods for measuring trends in incidence of OD. ${ }^{11}$ The aim is to estimate and compare true changes in incidence over time for five ODs comprising asthma, contact dermatitis (CD), noise-induced hearing loss (NIHL), carpal tunnel syndrome (CTS) and upper limb musculoskeletal disorders (ULMSD) across 10 European countries (Belgium, the Czech Republic, Finland, France, Italy, the Netherlands, Norway, Spain, Switzerland and the UK). These ODs were selected because they are a shared problem across Europe and incident data suitable for analysing trends were available for many countries. Furthermore, EU directives have addressed some of the relevant workplace exposures (eg, biological and chemical exposures, noise and vibration) ${ }^{12}$ and a reduction in incidence of $\mathrm{CD}$, asthma, NIHL and CTS caused by vibration might be expected. Reducing MSD (excluding CTS) has not been the main focus of an EU directive although several directives may have had an indirect effect. ${ }^{13}$

\section{METHODS}

All data from compensation schemes, other national registries, large networks of occupational physicians, workplace surveys and voluntary reporting schemes were initially considered eligible for inclusion, including population surveys based on selfdiagnosis by the worker. However, because disease categories used for self-diagnosed data tended to be too broad, it was decided to omit these sources. Only data from schemes which could potentially reflect nationally representative trends in incidence over time were included; thus one scheme, the Norwegian Labour Inspectorate's Registry of Work-Related diseases, illnesses $\&$ disorders, ${ }^{14}$ which had the primary aim of prompting regulatory action, was excluded. The remaining data were of two main types; data collected for claims of compensation for OD and data based on physician reporting.
In the main, the included schemes capture newly diagnosed (incident) cases as opposed to prevalent cases. However, since trends in prevalence may accurately reflect trends in incidence when mean disease duration does not change, one important prevalence survey (Maladies à Caractère Professionnel, MCP) ${ }^{15}$ was included. Where possible, denominator data (ie, population size) was also collected. Members of MODERNET were invited to source their data from 2000 onwards, or the earliest date from which the data were considered reliable; members from 10 countries were able to provide one or more data sets.

OD cases were defined using the WHO International Classification of Diseases (ICD-10) as listed below:

- CD: L23-L25, allergic CD: L23, irritant CD: L24

- Asthma: J45-J46

- NIHL: H83.3 Z57.0 H91.9, W42

- CTS: G56.0

- ULMSD: M18.0-M18.9, M19.9, M60-M79 involving sites 1-4 listed below-CTS is excluded from ULMSD

1. Shoulder region: clavicle, scapula, joints (acromioclavicular, glenohumeral and sternoclavicular)

2. Upper arm: humerus, elbow joint

3. Forearm: radius, ulna and wrist joint

4. Hand: carpus, fingers, metacarpus, joints between these bones

Some schemes were not able to match the exact case definitions, so exceptions to the definitions were made on an individual basis in order to be as inclusive as possible. If in the opinion of the authors the difference in definition did not invalidate comparisons between countries the data were included with a footnote. Therefore the Finnish data for ULMSDs does not include shoulder problems. The Belgium data for CD and asthma are not included since they could not be separated from all skin and all respiratory OD; this was also the case for Spain and skin diseases.

A detailed description and comparison of the OD surveillance systems for each EU country has been published. ${ }^{16}$ The methods of data collection for the countries included here are described online (see online supplementary file 1) and the characteristics of the data summarised in tables 1 and 2. The physicianreported data sets (table 1) included were:

- France: Le Réseau national de vigilance et de prévention des pathologies professionnelles (RNV3P) ${ }^{17}$

- France: $\mathrm{MCP}^{15}$

- Italy: Malattie Professionali surveillance system (MalProf) ${ }^{18}$

- The Netherlands: National registry. ${ }^{19}$ Two further registries consist of dermatologists and lung specialists

- Norway: The National Institute of Occupational Health ${ }^{20}$

- The UK: The Health and Occupation Research Network ${ }^{10}$

All the countries contributing compensation data have a national 'list' of OD for the purposes of recognition and compensation. Belgium, Finland, France, Italy and Switzerland have a 'mixed' system whereby, apart from the list, other diseases can be recognised subject to a higher burden of proof of causation by work that varies between countries. The Czech Republic, Spain and the UK have a 'closed' system whereby only OD on the national list can be recognised. All the countries except the UK legally require the reporting of suspected OD for insurance or compensation purposes. In most countries, this requirement falls on any physician (or occupational physician (OP) in Belgium) but in Switzerland the worker or employer is required to make the report. In the UK, reporting of some ODs to the Health and Safety Executive is required but this is independent of the compensation system. For all countries all recognised 
Table 1 Summary of characteristics of physician reported data

\begin{tabular}{|c|c|c|c|c|c|}
\hline Scheme & Indicators of coverage & $\begin{array}{l}\text { Important changes in reporting } \\
\text { system since } 2000\end{array}$ & $\begin{array}{l}\text { Decision maker on } \\
\text { work-relatedness }\end{array}$ & $\begin{array}{l}\text { Includes zero } \\
\text { reports* }\end{array}$ & Population offset \\
\hline France RNV3P & All 32 OD centres in France & $\begin{array}{l}\text { } 22 \text { centres from } 2001 \\
\text { - } 28 \text { centres from } 2002 \\
\text { - } 29 \text { centres from } 2004 \\
\text { - } 32 \text { centres from } 2007\end{array}$ & Reporting OP & Yes & $\begin{array}{l}\text { Estimated national } \\
\text { workforce }\end{array}$ \\
\hline France MCP & $\begin{array}{l}\text { 684-985 Ops (excludes civil } \\
\text { servant, military, education, } \\
\text { police) }\end{array}$ & Data collection started 2006 & Reporting OP & $\begin{array}{l}\text { Yes (for } \\
\text { periodic visits) }\end{array}$ & Actual size \\
\hline Italy & $\begin{array}{l}\text { - } 25 \% \text { population until } 2006 \\
\text { - } 50 \% \text { population post } 2006\end{array}$ & $\begin{array}{l}3 \text { further regions added } 2006 \\
\text { In } 2004 \text { changes in OD } \\
\text { compulsorily reported to local } \\
\text { health units }\end{array}$ & Reporting OP & No & $\begin{array}{l}\text { Total wages divided by } \\
\text { average wage per } \\
\text { employer }\end{array}$ \\
\hline $\begin{array}{l}\text { The Netherlands } \\
\text { (clinical specialist) }\end{array}$ & $\begin{array}{l}\text { - } \sim 20 \text { respiratory physicians } \\
\text { } \sim 30 \text { dermatologists }\end{array}$ & & Reporting physician & No & $\begin{array}{l}\text { Estimated national } \\
\text { workforce }\end{array}$ \\
\hline $\begin{array}{l}\text { The Netherlands } \\
\text { (OP) }\end{array}$ & $540-980$ OP & & Reporting OP & No & $\begin{array}{l}\text { Estimated national } \\
\text { workforce }\end{array}$ \\
\hline Norway & All 6 OD centres in Norway & Data collection started 2009 & Reporting OP & No & No \\
\hline $\begin{array}{l}\text { UK (Clinical } \\
\text { specialist) }\end{array}$ & $\begin{array}{l}\text { 440-530 respiratory } \\
\text { physicians } \\
\text { - } 160-200 \text { dermatologists } \\
\text { 240-320 rheumatologists } \\
\text { - } 7-14 \text { audiologists }\end{array}$ & $\begin{array}{l}\text { Data collection ended: } \\
\text { - Rheumatologists } 2009 \\
\text { - Audiologists } 2006\end{array}$ & Reporting physician & Yes & $\begin{array}{l}\text { Estimated national } \\
\text { workforce }\end{array}$ \\
\hline UK (OP) & $330-550$ OP & & Reporting OP & Yes & $\begin{array}{l}\text { Estimated from survey of } \\
\text { OP reporters }\end{array}$ \\
\hline
\end{tabular}

compensation claims (for both temporary and permanent disability) were analysed. The term 'recognised compensation claim' means that the OD has been formally accepted with respect to diagnosis and work-relatedness but compensation is not always paid. Usually the OD has to reach a level of disability defined by each country before payment. The denominator was the government estimates of the working population for all countries except France and Italy. For France, the denominator was all salaried workers covered by Caisse Nationale de l'Assurance Maladie des Travailleurs Salariés. ${ }^{21}$ This excludes self-employed persons, job seekers, civil servants and agricultural workers, and therefore is different to the RNV3P denominator (the government estimated working population of France). For Italy, the population covered by the Italian Workers' Compensation Authority was estimated by dividing the total wages paid by each employer by the respective average wage after excluding the highest and lowest earners. ${ }^{22}$ The compensation data sets included were (table 2):

- Belgium: Belgium Compensation Fund for $\mathrm{OD}^{23}$

- The Czech Republic: Czech Registry of OD ${ }^{24}$

- Finland: The Finnish Register of $\mathrm{OD}^{25}$

- France: Caisse Nationale de l'Assurance Maladie des Travailleurs Salariés ${ }^{21}$

- Italy: Italian Workers' Compensation Authority ${ }^{22}$

- Spain: OD Registry of the Social Security System ${ }^{26}$

- Switzerland: Central Office for Statistics in Accident Insurance $^{27}$

- Great Britain (the UK excluding Northern Ireland): Department of Work and Pensions ${ }^{28}$

\section{Statistical methods}

For all data sets, case counts were analysed using a negative binomial regression model with year as the main predictor of interest; the negative binomial is a generalisation of the Poisson model, which allows a greater degree of random variability. To estimate true change in national incidence rate over time when a scheme is known to have incomplete capture of relevant cases, it is important to take account of simultaneous change over time in the size of the population covered. Even with complete coverage, this is needed if the size of the national workforce changes. Therefore, population estimates were included in the regression model as an 'offset'; (in Stata the correct offset is the logarithm of the population size). In some schemes with incomplete coverage and no direct estimates of population size, the size of the national workforce was used instead; this is a crude adjustment, which presumes that proportional year to year changes in the national workforce would also be reflected in the workforce covered by the scheme.

The data were available separately for each reporting centre in the scheme for all the physician-reported schemes and one compensation dataset (the Czech Republic). In these cases, a multilevel version of the negative binomial model was used, usually with reporting physician or centre as a 'random effect'. Insofar as this model can estimate 'within-centre' change over time, it is not affected by changes over time in the number of centres itself. Furthermore, it allows for between-centre variation in incidence and thereby produces more accurate $p$ values and CIs than the simple negative binomial model. Other covariates were included for some countries, either as a means of reducing bias (eg, first month as a reporter since there might be possible over-reporting or under-reporting), or to explain some of the variability and hence reduce SDs.

The French MCP data were treated differently according to whether cases came from the periodic survey of workers or presented by another route. For the former, a complicated but rigorous survey design, with working groups judged at higher risk seen more frequently, had been used but good denominator data were available to allow for this. Groups defined by the occupation and employment sector were used to define the random effects and the denominators were the total number of workers within each occupation/employment sector group undergoing a periodic visit each year. For ODs arising from all 
Table 2 Summary of characteristics of compensation data

\begin{tabular}{|c|c|c|c|c|}
\hline Country & Excluded workers & Person initiating claim & Person(s) recognising the claim & Changes in reporting since 2000 \\
\hline Belgium & $\begin{array}{l}\text { Self-employed } \\
\text { Military } \\
\text { - Some government officials }\end{array}$ & $\begin{array}{l}\text { Any physician in agreement of } \\
\text { worker }\end{array}$ & $\begin{array}{l}\text { Physician employed by state insurance } \\
\text { company }\end{array}$ & Data available from 2001 \\
\hline $\begin{array}{l}\text { The Czech } \\
\text { Republic }\end{array}$ & $\begin{array}{l}\text { Self-employed } \\
\text { Home workers }\end{array}$ & Any physician & Physician in OD centre & $\begin{array}{l}\text { Minor update of the national list in } \\
2011 \text { (six items added) }\end{array}$ \\
\hline France & $\begin{array}{l}\text { Self-employed } \\
\text { Civil servants } \\
\text { Farmers }\end{array}$ & $\begin{array}{l}\text { Worker } \\
\text { Physician provides medical } \\
\text { certificate }\end{array}$ & Local health insurance fund employees & Data available from 2004 \\
\hline Finland & None & $\begin{array}{l}\text { Physician } \\
\text { - Employer }\end{array}$ & Physician in insurance company & Data available from 2005 \\
\hline Italy & $\begin{array}{l}\text { Must be on list of risky } \\
\text { activities includes } 80 \% \text { of } \\
\text { population }\end{array}$ & $\begin{array}{l}\text { Worker-directly or through } \\
\text { employer }\end{array}$ & $\begin{array}{l}\text { Legal specialists, OP and technical } \\
\text { experts employed by state insurance } \\
\text { company }\end{array}$ & $\begin{array}{l}\text { Change to national list of OD in } 2008 \\
\text { making it easier to claim for CTS and } \\
\text { ULMSD }\end{array}$ \\
\hline Spain* & $\begin{array}{l}\text { None Includes self-employed } \\
\text { since } 2003 \text { (voluntary) }\end{array}$ & $\begin{array}{l}\text { Physicians of the National } \\
\text { Health Service } \\
\text { OPs from Mutual Societies }\end{array}$ & Administrative unit of the Social Security & $\begin{array}{l}\text { Change to national list in } 2007 \text { and } \\
\text { new electronic reporting system }\end{array}$ \\
\hline Switzerland & $\begin{array}{l}\text { - Self-employed } \\
\text { Military }\end{array}$ & $\begin{array}{l}\text { Worker } \\
\text { Employer } \\
\text { any person with worker's } \\
\text { consent for example, } \\
\text { physician }\end{array}$ & $\begin{array}{l}\text { Consultant physician of insurance } \\
\text { company }\end{array}$ & None relevant to these data \\
\hline GB & Self-employed & Worker & Government department with OP advice & None relevant to these data \\
\hline
\end{tabular}

other visits, the random effects were defined by region (because the occupation/sector information was not available) and the denominator was the population allocated to the participating OP within that region.

The purpose of the analyses was to estimate change in incidence and not absolute incidence. All models expressed the results for each year in each scheme as a rate ratio (RR) with 2007 as the reference year. In other models, so as to provide a simple summary of annual rate of change, time was included as a continuous variable; these models estimate the RR for 1 year relative to the preceding one, assuming that there is a constant change over time; the average annual change is shown as RR-1.

For some schemes there were changes in compensation rules or reporting methods (tables 1 and 2) at specific dates; these changes would be expected to result in artefactual changes in case counts. Where this occurred, an adjusted annual change in incidence was estimated after including in the analysis a variable coded $0 / 1$ according to whether data were from before or after the change in rules. The year to year changes shown in the Figures remained unadjusted so the impact of such changes can be clearly seen (figures 1 and 2 and see online supplementary figures S1-S4 online). These a priori adjustments were made for the reasons given below:

- Italy: In 2004 changes were made to the list specifying which ULMSD cases physicians must report to the Local Health Units. In 2008 changes were made to the national list of compensated OD relevant to CTS and ULMSD.

- The Netherlands: From 2009 a subset of approximately 170 reporters began reporting to a sentinel scheme within the National Registry. These reporters receive more training in the reporting guidelines and cover a defined population.

- Spain: In 2007 legislation promoting OD notification by physicians was introduced, the national list of ODs was updated and an electronic reporting system was introduced.

Whether or not data were considered missing depended on the expectations of the surveillance scheme. In the UK, physician-reporters were asked to return a report even when no cases of OD had been seen in that month; if a reporter did not return a report, that month was excluded from the analysis. There were no missing data for France (MCP), as a physician
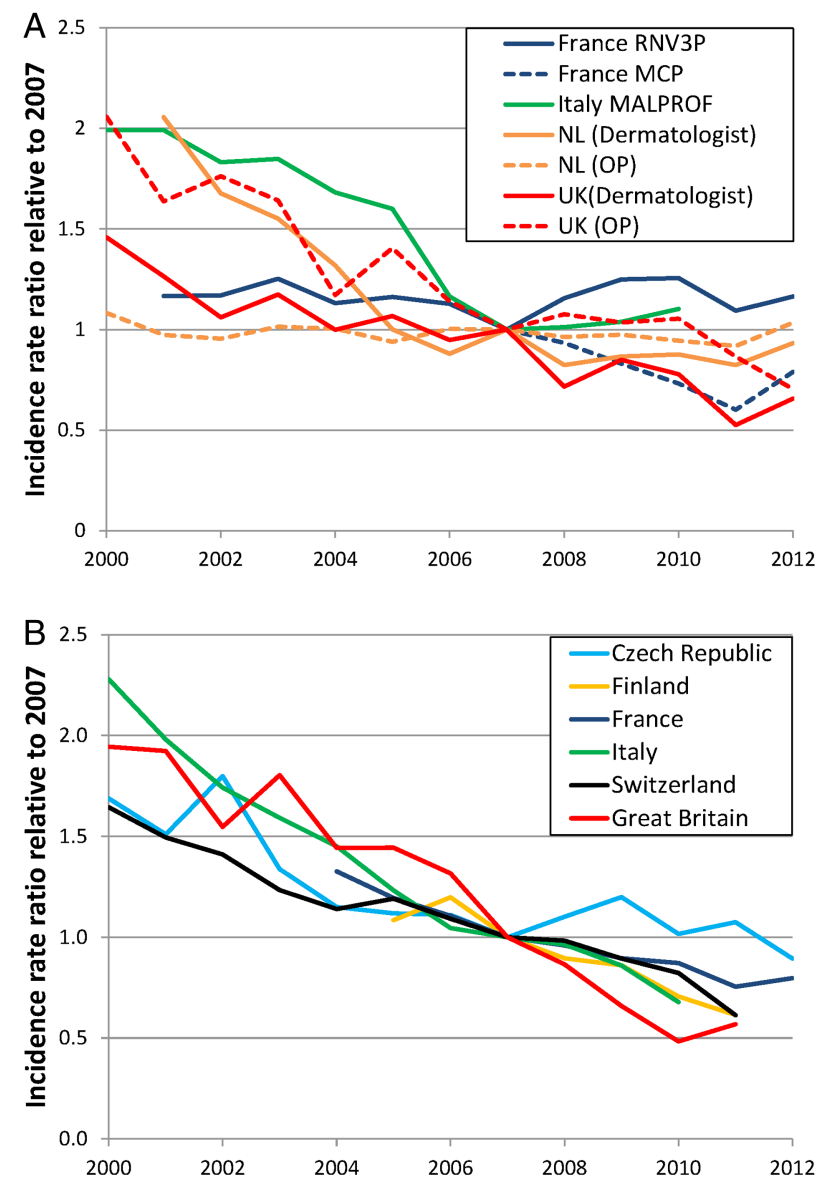

Figure 1 Estimated annual changes in incidence of occupational contact dermatitis; physician reported (A) and recognised compensation claims (B). 

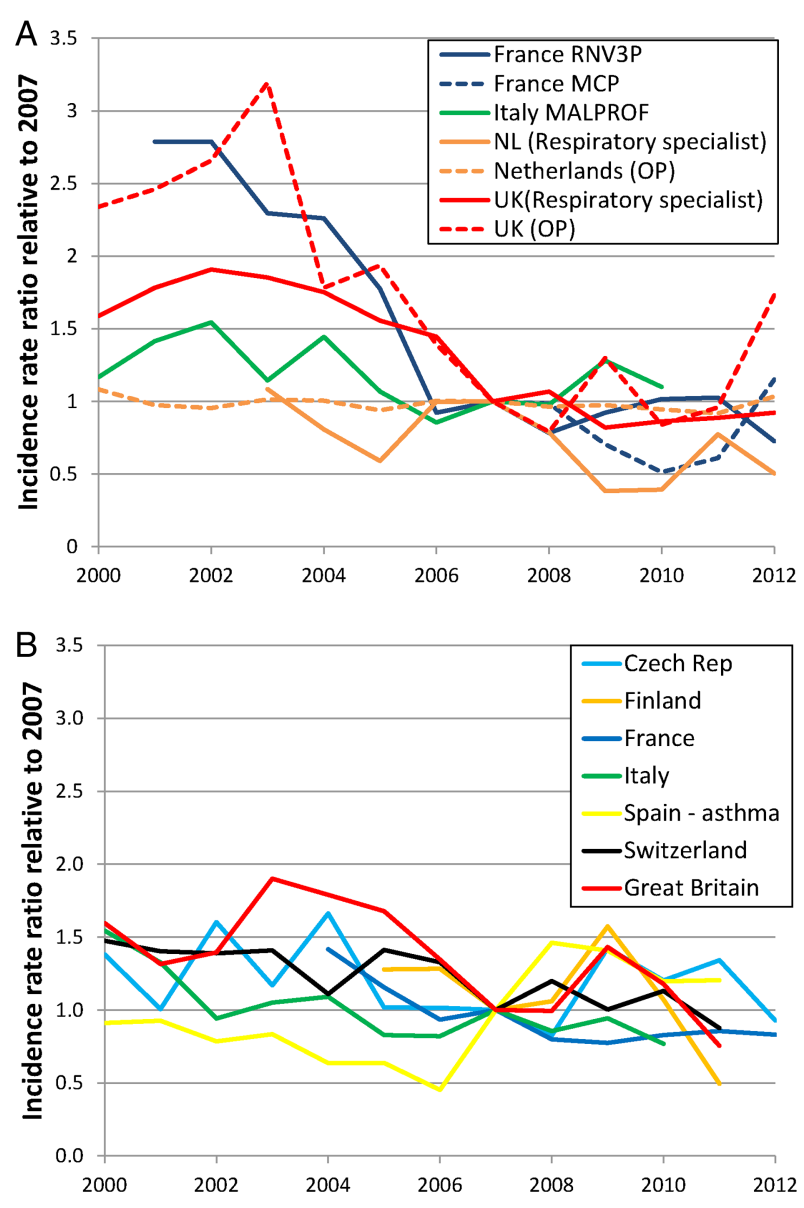

Figure 2 Estimated annual changes in incidence of occupational asthma; physician reported (A) and recognised compensation claims (B).

was counted as participating by contributing data. The French (RNV3P), Italian (Malprof) and the Netherlands centres were only expected to report if they had seen cases. For RNV3P, if no cases were reported it was assumed that there were zero cases for that month, that is, no missing data. For the Netherlands, it was likely the centre had ceased to report, and for Italy there was no method of establishing whether it was a zero or missing report. In both countries those centres were excluded from the analysis for that year. For all compensation schemes cases were always reported, that is, no missing data.

\section{RESULTS}

The estimated annual change in incidence for each country and OD spanning the time period for which each country had data available is shown in table 3 . The annual mean number of cases shown in table 3 is to inform the interpretation of the results and is not intended to reflect the absolute incidence of OD within each country. Eight countries were able to provide data spanning 2001 to 2010, allowing direct comparisons between Belgium, the Czech Republic, France, Italy, the Netherlands, Spain, Switzerland and the UK, as shown in table 4. The annual changes for $\mathrm{CD}$ and asthma relative to 2007 are shown in figures 1 and 2 and for allergic and irritant CD, NIHL, CTS and ULMSD in online supplementary figures 1-4 (online only). Data collection within the Norwegian National Institute of Occupational Health began in 2009 and the UK audiologist reporting scheme ended in 2006; therefore, these data are not included in the Figures that show change relative to 2007.
There was a significant decline in incidence of physicianreported and of recognised compensation claims for CD in most countries (tables 3 and 4, figure 1); exceptions are Norway, where there appeared to be an increase, (table 3), and France and the Netherlands, where there were mixed messages. The Norwegian data collection is still being established and the results may reflect instability during the start-up period. In France, recognised compensation claims and reporting by MCP physicians show a declining trend but reporting by RNV3P physicians shows no change. In the Netherlands, dermatologists reported a declining trend whereas OP reported no change. For some countries, cases of allergic and irritant CD were available and generally both show a declining trend (tables 3 and 4, see online supplementary figure S1). In the UK and the Czech Republic there is a decline in allergic but not irritant CD.

There is no evidence of increasing incidence of asthma (tables 3 and 4, figure 2). In France and the UK, the decline in physician-reported asthma occurred mainly before 2007 (figure 2A). The sharp increase in recognised compensation claims during 2007 in Spain (figure 2) was likely due to the changes in legislation and reporting methods described above as well as to a new classification of occupational asthma that included cases previously reported in other categories; after adjusting for this change there was a non-significant decline in incidence $(-3.7 ;-8.4$ to 1.3 , table 3$)$. Countries with more than one dataset spanning 2001 to 2010 (Italy, the Netherlands, the UK compared with GB) did not show differences in direction of the trend between schemes within the same country (table 4, figure 2), although not all changes were statistically significant.

Modest increases in NIHL were reported in the Netherlands, Belgium and Switzerland, with a larger increase in Spain. All other countries reported a significantly declining trend (tables 3 and 4, see online supplementary figure S2).

The incidence of recognised compensation claims for CTS is increasing in Belgium, the Czech Republic, France, Spain and decreasing in Great Britain (the UK excluding Northern Ireland); elsewhere there was no significant change. On the other hand, physician-reported CTS is not changing or declining except in Italy (tables 3 and 4, see online supplementary figure S3). In France, the increase in recognised compensation claims is in the opposite direction to downward trends in physicianreporting (table 3). Similarly, in the UK, the early trend (pre-2003) of increasing recognised compensation claims for CTS (GB) was not observed in the physician-reported CTS; however, the decline post 2003 occurred in recognised compensation claims as well as in physician-reported data (see online supplementary figure S3).

Changes in the reported incidence of ULMSD varied greatly in direction as well as magnitude (tables 3 and 4, see online supplementary figure S4). Physician-reported trends showed a decreasing trend in the UK and the Netherlands, with no change in France (MCP), but Italy and France (RNV3P) showed increasing trends particularly post 2007 that were matched in the recognised compensation claims. Switzerland and Finland showed a decreasing trend in ULMSD whereas there was no significant change in the Czech Republic.

\section{DISCUSSION}

We have presented direct comparisons of the trends in incidence of physician-reported and recognised compensation claims for OD between European countries for the first time (table 4). To do so, we had to develop a statistical methodology that would be flexible enough to encompass the diverse data structures and 
Table 3 Estimated annual percentage change (RR-1)\% in incidence for physician-reported and recognised compensation cases, 95\% Cls and annual mean number of reported cases

\begin{tabular}{|c|c|c|c|c|c|c|c|c|}
\hline \multirow[b]{2}{*}{ Country } & \multirow[b]{2}{*}{ Years } & \multicolumn{7}{|c|}{ Physician-reported-annual \% change $95 \% \mathrm{Cl}$ (annual mean number of cases) } \\
\hline & & Contact dermatitis & $\begin{array}{l}\text { Allergic contact } \\
\text { dermatitis }\end{array}$ & $\begin{array}{l}\text { Irritant contact } \\
\text { dermatitis }\end{array}$ & Asthma & $\begin{array}{l}\text { Noise-induced } \\
\text { hearing loss }\end{array}$ & $\begin{array}{l}\text { Carpal tunnel } \\
\text { syndrome }\end{array}$ & $\begin{array}{l}\text { Upper limb musculoskeletal } \\
\text { disorders }\end{array}$ \\
\hline \multicolumn{9}{|c|}{ Physician-reported—annual \% change $95 \% \mathrm{Cl}$ (annual mean number of cases) } \\
\hline France (RNV3P) & $2001-2012$ & $\begin{array}{l}0.1 \\
-1.0 \text { to } 0.7(575)\end{array}$ & $\begin{array}{l}1.0 \\
0.0 \text { to } 2.0 \text { (374) }\end{array}$ & $\begin{array}{l}-2.3 \\
-3.5 \text { to }-1.0(201)\end{array}$ & $\begin{array}{l}-13.6 \\
-14.7 \text { to }-12.4(209)\end{array}$ & $\begin{array}{l}-6.5 \\
-7.8 \text { to }-5.0(194)\end{array}$ & $\begin{array}{l}-1.7 \\
-3.0 \text { to } 0.3(137)\end{array}$ & $\begin{array}{l}12.6 \\
11.2 \text { to } 14.0(378)\end{array}$ \\
\hline France (MCP) & 2007-2012 & $\begin{array}{l}-7.5 \\
-11.9 \text { to }-2.9(148)\end{array}$ & - & - & $\begin{array}{l}-2.6 \\
-12.3 \text { to } 8.2(28)\end{array}$ & $\begin{array}{l}-17.0 \\
-20.8 \text { to }-13.1 \text { (247) }\end{array}$ & $\begin{array}{l}-6.5 \\
-9.3 \text { to }-3.5(396)\end{array}$ & $\begin{array}{l}0.3 \\
-2.3 \text { to } 1.7(1424)\end{array}$ \\
\hline Italy & $2000-2010$ & $\begin{array}{l}-7.8 \\
-9.6 \text { to }-6.0(171)\end{array}$ & - & - & $\begin{array}{l}-2.7 \\
-4.8 \text { to }-1.6(41)\end{array}$ & $\begin{array}{l}-5.4 \\
-7.2 \text { to }-3.6(1697)\end{array}$ & $\begin{array}{l}6.1 \\
3.2 \text { to } 9.1(256)\end{array}$ & $\begin{array}{l}14.6 \\
7.3 \text { to } 22.4(287)\end{array}$ \\
\hline $\begin{array}{l}\text { The Netherlands (clinical } \\
\text { specialist) }\end{array}$ & $2001-2012$ & $\begin{array}{l}-9.2 \\
-11.4 \text { to }-7.0(498)\end{array}$ & - & - & $-5.7-13.8$ to $3.3(21)$ & - & - & - \\
\hline The Netherlands (OP) & 2000-2012 & $\begin{array}{l}-0.6 \\
-1.9 \text { to } 0.7(145)\end{array}$ & - & - & $\begin{array}{l}-0.9 \\
-3.7 \text { to } 2.0(25)\end{array}$ & $\begin{array}{l}1.8 \\
0.5 \text { to } 3.1 \text { (1982) }\end{array}$ & $\begin{array}{l}0.5 \\
-1.5 \text { to } 2.6(61)\end{array}$ & $\begin{array}{l}-2.6 \\
-3.2 \text { to }-2.0(1452)\end{array}$ \\
\hline Norway & 2010-2012 & $\begin{array}{l}33.3 \\
11.4 \text { to } 59.7(62)\end{array}$ & - & - & $\begin{array}{l}-16.5 \\
-25.4 \text { to }-6.6(170)\end{array}$ & - & - & - \\
\hline UK (clinical specialist) & $2000-2012$ & $\begin{array}{l}-3.0 \\
-3.9 \text { to }-2.1(780)\end{array}$ & $\begin{array}{l}-6.2 \\
-7.3 \text { to }-5.0(409)\end{array}$ & $\begin{array}{l}-0.5 \\
-1.7 \text { to } 0.7 \text { (475) }\end{array}$ & $\begin{array}{l}-7.6 \\
-9.3 \text { to }-5.9(115)\end{array}$ & $\begin{array}{l}-20.4^{*} \\
-24.3 \text { to }-16.2(110)\end{array}$ & $\begin{array}{l}-6.2 \dagger \\
-10.6 \text { to }-1.6(40)\end{array}$ & $\begin{array}{l}-6.9 \dagger \\
-10.6 \text { to }-3.0(157)\end{array}$ \\
\hline UK (OP) & 2000-2012 & $\begin{array}{l}-6.9 \\
-9.2 \text { to }-4.5(90)\end{array}$ & - & - & $\begin{array}{l}-7.2 \\
-11.5 \text { to }-2.7(22)\end{array}$ & - & $\begin{array}{l}-0.6 \\
-5.0 \text { to } 4.1(23)\end{array}$ & $\begin{array}{l}-5.4 \\
-7.0 \text { to }-3.7 \text { (192) }\end{array}$ \\
\hline \multicolumn{9}{|c|}{ Recognised compensation-annual \% change $95 \% \mathrm{Cl}$ (annual mean number of cases) } \\
\hline Belgium & 2000-2012 & - & - & & - & $\begin{array}{l}2.4 \\
0.9 \text { to } 3.9(692)\end{array}$ & $\begin{array}{l}5.9 \\
2.6 \text { to } 9.3 \text { (697) }\end{array}$ & - \\
\hline The Czech Republic & $2000-2012$ & $\begin{array}{l}-4.7 \\
-6.8 \text { to }-2.5(245)\end{array}$ & $\begin{array}{l}-7.7 \\
-9.2 \text { to }-6.2(196)\end{array}$ & $\begin{array}{l}-0.5 \\
-3.4 \text { to } 2.6(49)\end{array}$ & $\begin{array}{l}-1.7 \\
-4.6 \text { to } 1.3(49)\end{array}$ & $\begin{array}{l}-3.8 \\
-6.6 \text { to }-0.9 \text { (34) }\end{array}$ & $\begin{array}{l}2.9 \\
(1.1 \text { to } 4.6)(348)\end{array}$ & $\begin{array}{l}1.9 \\
-0.1 \text { to } 4.0(159)\end{array}$ \\
\hline Finland & 2005-2011 & $\begin{array}{l}-9.8 \\
-12.1 \text { to }-7.4(441)\end{array}$ & $\begin{array}{l}-9.3 \\
-11.9 \text { to }-6.6(203)\end{array}$ & $\begin{array}{l}-9.2 \\
-11.8 \text { to }-6.6(203)\end{array}$ & $\begin{array}{l}-7.7 \\
-17.0 \text { to } 2.7(127)\end{array}$ & $\begin{array}{l}-8.7 \\
-13.2 \text { to }-3.9(1026)\end{array}$ & $\begin{array}{l}3.8 \\
-3.8 \text { to } 11.9(24)\end{array}$ & $\begin{array}{l}-16.5 \ddagger \\
-18.2 \text { to }-14.8(358)\end{array}$ \\
\hline France & 2004-2012 & $\begin{array}{l}-6.9 \\
-8.0 \text { to }-6.2(954)\end{array}$ & $\begin{array}{l}-6.9 \\
-7.8 \text { to }-6.0(917)\end{array}$ & $\begin{array}{l}-10.1 \\
-14.1 \text { to }-5.9(37)\end{array}$ & $\begin{array}{l}-6.8 \\
-8.4 \text { to }-5.1(318)\end{array}$ & $\begin{array}{l}-3.8 \\
-4.7 \text { to }-2.9(1145)\end{array}$ & $\begin{array}{l}10.5 \\
9.6 \text { to } 11.4 \text { (18141) }\end{array}$ & $\begin{array}{l}12.0 \\
11.1 \text { to } 12.9(1806)\end{array}$ \\
\hline Italy & 2000-2010 & $\begin{array}{l}-10.7 \\
-11.6 \text { to }-9.8(350)\end{array}$ & - & - & $\begin{array}{l}-5.1 \\
-7.3 \text { to }-2.8(115)\end{array}$ & $\begin{array}{l}-5.2 \\
-8.2 \text { to }-2.0(1429)\end{array}$ & - & $\begin{array}{l}18.3 \\
16.3 \text { to } 20.4(2116)\end{array}$ \\
\hline Spain & 2000-2011 & - & - & - & $\begin{array}{l}-3.7 \\
-8.4 \text { to } 1.3(336)\end{array}$ & $\begin{array}{l}9.8 \\
4.2 \text { to } 15.6(766)\end{array}$ & $\begin{array}{l}3.9 \\
1.0 \text { to } 7.0(2300)\end{array}$ & - \\
\hline Switzerland & 2000-2011 & $\begin{array}{l}-7.0 \\
-8.1 \text { to }-5.8(754)\end{array}$ & $\begin{array}{l}-7.2 \\
-8.8 \text { to }-5.5(420)\end{array}$ & $\begin{array}{l}-7.0 \\
-8.6 \text { to }-5.4(334)\end{array}$ & $\begin{array}{l}-3.8 \\
-5.6 \text { to }-2.1(156)\end{array}$ & $\begin{array}{l}3.2 \\
1.6 \text { to } 4.9 \text { (514) }\end{array}$ & - & $\begin{array}{l}-11.5 \\
-12.5 \text { to }-10.6(351)\end{array}$ \\
\hline $\begin{array}{l}\text { Great Britain (UK data n/ } \\
\text { a) }\end{array}$ & $2000-2011$ & $\begin{array}{l}-11.6 \\
-13.7 \text { to }-9.5(140)\end{array}$ & - & - & $\begin{array}{l}-4.7 \\
-7.7 \text { to }-1.5(80)\end{array}$ & $\begin{array}{l}-5.3 \\
-7.8 \text { to }-2.7(235)\end{array}$ & $\begin{array}{l}-5.1 \\
-8.7 \text { to }-1.5(604)\end{array}$ & - \\
\hline
\end{tabular}


Table 4 Estimated annual percentage change (RR-1)\% in incidence for physician reported and recognised compensation cases, 95\% Cls from 2001 to 2010

\begin{tabular}{|c|c|c|c|c|c|c|c|}
\hline Country & $\begin{array}{l}\text { Contact } \\
\text { dermatitis }\end{array}$ & $\begin{array}{l}\text { Allergic Contact } \\
\text { dermatitis }\end{array}$ & $\begin{array}{l}\text { Irritant Contact } \\
\text { dermatitis }\end{array}$ & Asthma & $\begin{array}{l}\text { Noise-induced } \\
\text { hearing loss }\end{array}$ & $\begin{array}{l}\text { Carpal tunnel } \\
\text { syndrome }\end{array}$ & $\begin{array}{l}\text { Upper limb } \\
\text { musculoskeletal } \\
\text { disorders }\end{array}$ \\
\hline \multicolumn{8}{|c|}{ Physician-reported—annual \% change $95 \% \mathrm{Cl}$} \\
\hline France (RNV3P) & $\begin{array}{l}0.1 \\
-0.9 \text { to } 1.1\end{array}$ & $\begin{array}{l}1.8 \\
0.6 \text { to } 3.0\end{array}$ & $\begin{array}{l}-3.1 \\
-4.6 \text { to }-1.6\end{array}$ & $\begin{array}{l}-14.8 \\
-16.1 \text { to }-13.5\end{array}$ & $\begin{array}{l}-2.1 \\
-3.8 \text { to }-0.5\end{array}$ & $\begin{array}{l}-1.4 \\
-3.1 \text { to } 0.2\end{array}$ & $\begin{array}{l}14.7 \\
12.9 \text { to } 16.5\end{array}$ \\
\hline Italy & $\begin{array}{l}-8.4 \\
-10.5 \text { to }-6.4\end{array}$ & - & - & $\begin{array}{l}-3.7 \\
-6.0 \text { to }-1.3\end{array}$ & $\begin{array}{l}-5.9 \\
-7.9 \text { to }-3.9\end{array}$ & $\begin{array}{l}7.1 \\
3.9 \text { to } 10.5\end{array}$ & $\begin{array}{l}13.9 \\
5.9 \text { to } 22.6\end{array}$ \\
\hline $\begin{array}{l}\text { The Netherlands (clinical } \\
\text { specialist) }\end{array}$ & $\begin{array}{l}-10.8 \\
-13.3 \text { to }-8.3\end{array}$ & - & - & $\begin{array}{l}-9.1 \\
-19.0 \text { to } 2.1\end{array}$ & - & - & - \\
\hline The Netherlands (OP) & $\begin{array}{l}-0.3 \\
-2.4 \text { to } 1.8\end{array}$ & - & - & $\begin{array}{l}-0.8 \\
-5.6 \text { to } 4.3\end{array}$ & $\begin{array}{l}3.0 \\
1.0 \text { to } 5.0\end{array}$ & $\begin{array}{l}0.6 \\
-2.8 \text { to } 4.2\end{array}$ & $\begin{array}{l}-3.4 \\
-4.4 \text { to }-2.4\end{array}$ \\
\hline The UK (clinical specialist) & $\begin{array}{l}-3.0 \\
-4.0 \text { to }-1.8\end{array}$ & $\begin{array}{l}-6.3 \\
-7.9 \text { to }-4.7\end{array}$ & $\begin{array}{l}-0.2 \\
-1.7 \text { to } 1.4\end{array}$ & $\begin{array}{l}-9.1 \\
-11.2 \text { to }-5.9\end{array}$ & - & - & - \\
\hline The UK (OP) & $\begin{array}{l}-6.7 \\
-9.9 \text { to }-3.5\end{array}$ & - & - & $\begin{array}{l}-11.9 \\
-17.6 \text { to }-5.8\end{array}$ & - & $\begin{array}{l}-4.3 \\
-10.5 \text { to } 2.2\end{array}$ & $\begin{array}{l}-6.2 \\
-8.4 \text { to }-4.0\end{array}$ \\
\hline \multicolumn{8}{|c|}{ Recognised compensation-annual \% change $95 \% \mathrm{Cl}$ (annual mean number of cases) } \\
\hline Belgium & - & - & - & - & $\begin{array}{l}1.5 \\
-0.8 \text { to } 3.9\end{array}$ & $\begin{array}{l}1.2 \\
-2.8 \text { to } 5.4\end{array}$ & - \\
\hline Czech Republic & $\begin{array}{l}-4.8 \\
-8.0 \text { to }-1.5\end{array}$ & $\begin{array}{l}-8.1 \\
-10.1 \text { to }-6.0\end{array}$ & $\begin{array}{l}-1.1 \\
-5.4 \text { to } 3.5\end{array}$ & $\begin{array}{l}-1.7 \\
-5.6 \text { to } 2.4\end{array}$ & $\begin{array}{l}-1.1 \\
-5.0 \text { to } 2.9\end{array}$ & $\begin{array}{l}4.7 \\
(2.3 \text { to } 7.0)\end{array}$ & $\begin{array}{l}4.5 \\
1.5 \text { to } 7.6\end{array}$ \\
\hline Italy & $\begin{array}{l}-10.5 \\
-11.6 \text { to }-9.4\end{array}$ & - & - & $\begin{array}{l}-3.8 \\
-6.1 \text { to }-1.5\end{array}$ & $\begin{array}{l}-1.8 \\
-3.3 \text { to }-0.3\end{array}$ & - & $\begin{array}{l}19.0 \\
16.7 \text { to } 21.5\end{array}$ \\
\hline Spain & - & - & - & $\begin{array}{l}-3.1 \\
-9.5 \text { to } 3.7\end{array}$ & $\begin{array}{l}9.5 \\
2.1 \text { to } 17.4\end{array}$ & $\begin{array}{l}1.8 \\
-1.3 \text { to } 5.0\end{array}$ & - \\
\hline Switzerland & $\begin{array}{l}-6.0 \\
-6.7 \text { to }-5.3\end{array}$ & $\begin{array}{l}-6.1 \\
-7.5 \text { to }-4.7\end{array}$ & $\begin{array}{l}-6.5 \\
-8.2 \text { to }-4.6\end{array}$ & $\begin{array}{l}-3.2 \\
-5.1 \text { to }-1.3\end{array}$ & $\begin{array}{l}4.7 \\
2.9 \text { to } 6.6\end{array}$ & - & $\begin{array}{l}-11.6 \\
-12.7 \text { to }-10.6\end{array}$ \\
\hline Great Britain (UK data NA) & $\begin{array}{l}-12.5 \\
-15.2 \text { to }-9.8\end{array}$ & - & - & $\begin{array}{l}-3.7 \\
-7.4 \text { to } 0.3\end{array}$ & $\begin{array}{l}-6.0 \\
-8.3 \text { to }-3.2\end{array}$ & $\begin{array}{l}-7.9 \\
-11.5 \text { to }-4.1\end{array}$ & - \\
\hline
\end{tabular}


availabilities of denominator adjustments in 20 data sets from 10 European countries. Our central tenet is that, in principle, valid comparisons of the change in incidence of OD can be made without complete harmonisation of the methods of data collection, provided careful attention is paid to potential biases (see below). As anticipated, the number of actual reports from each data scheme varied widely (table 3 ). Precise population denominators to allow estimates of incidence were rarely available and comparisons between the numbers of reported cases are not meaningful, rather they are included to give an indication of the reliability of the estimates.

Preventative interventions-or lack of - by national agencies would be expected to lead to consistency of trends within countries, as was observed for most ODs, although not necessarily between countries. An important question is whether European legislation to reduce exposures has had an effect across member states. For the ODs with short latency, that is, CD and asthma, the temporal coincidence between the decline in incidence and legislation targeting exposure to chemical agents ${ }^{29} 30$ is consistent with a positive impact, but these data do not directly support any causal relationship. We cannot make any inferences regarding legislation to reduce exposure to physical agents, for example, noise, ${ }^{31}$ due to the indeterminate lag between exposure and OD.

We have adjusted for a priori changes in the compensation or reporting rules in the regression model but nonetheless interpretation of these trends should be cautious. There are several sources of bias to consider when forming an opinion about whether or not these changes in reported incidence are a proxy for changes in true incidence. An increasing trend may well indicate improved case ascertainment, improvements in legislation to protect workers that often require improved health surveillance, campaigns to draw attention to OD or simply a reporting scheme becoming established, as for the Norwegian dataset. Conversely, a decreasing trend could indicate a reduction in surveillance or access to healthcare, workers choosing not to seek advice due to poor job security or reporter fatigue as well as a genuine reduction in incidence. Additionally, changes in knowledge and opinions about OD among physicians and patients over time can impact in either direction.

Reporter fatigue occurs when voluntary reporters lose enthusiasm for reporting over time and has been observed in the UK, ${ }^{10}$ and is thought to occur in the Netherlands. Schemes where voluntary reporting is more integrated into routine care, such as in France, or part of a larger process of mandatory reporting, as in Italy, may be less prone to this bias. An indication of this problem would be if several distinct ODs originating from the same group of reporters show similar downward trends as observed in the UK OP reporting here.

'Harvesting' of cases can occur when new reporters enthusiastically report cases first diagnosed in the past; for schemes with monthly reports it was considered in the model (UK and France). Alternatively, it can occur when an incentive to report emerges. For example, in Italy in 2008, changes to the national list made it easier to claim for CTS and MSD, resulting in a harvesting of existing cases of CTS and ULMSD. It may also occur when changes in the healthcare system indirectly affect reporting. In the Netherlands in 2009, the construction industry changed their procedures for periodic health examinations, allowing for the reporting of codiagnosed OD potentially prompting harvesting, for example, NIHL might be a frequent secondary diagnosis in construction workers.
Media campaigns can be a factor in increasing reporting. For example, in Spain, an increase in NIHL occurred in 2007, particularly in the Basque region, and may be due to a local trade-union campaign aiming to promote reporting of NIHL. ${ }^{32}$ In France, tackling MSD was prioritised by the government in the occupational health plan $2005-2009 .^{33}$ A campaign to encourage preventative actions and raise awareness of MSD included setting of targets for employers and a high-profile national multimedia campaign from 2008 to $2010 .^{34}$ Furthermore, extensive coverage in the medical press may have changed physicians' opinions about MSD and, therefore, their referral behaviour. This might explain the increase in compensated and physician-reported (RNV3P) ULMSD and CTS around 2008. Such increases were not observed within the MCP data, possibly because these do not include recognised compensation claims and do not include those ODs sufficiently disabling enough to prevent attendance at work. In general, an increase in recognised compensation claims without an accompanying increase in physician-reported data might be considered positive; it may reflect improved awareness of risks and entitlement to benefits among workers, even though the true incidence may not be increasing.

Reporting of recognised compensation claims may arguably be less susceptible to bias in the diagnosis or attribution to work than physician-reported disease, since it is subject to welldefined, consistent rules and any changes to these rules will be documented. The downside to this accuracy is that it may only measure the tip of the iceberg, particularly in countries such as the UK, where general benefits cover everyone and only the most disabled workers receive additional benefits. However, changes in the incidence of the worst cases may also reflect changes overall. In countries where compensation is expected to cover healthcare costs, the frequency of compensation claims might also be affected by the removal of other benefits. For example, the increasing trend in NIHL in Switzerland may have been due to a reduction in the provision of hearing aids from other insurers, prompting workers to claim from the Swiss National Accident Insurance Fund. This is consistent with surveillance of 40000 exposed employees by the Swiss National Accident Insurance Fund audiometry programme where there was no apparent increase in the incidence of NIHL. ${ }^{35}$ Furthermore, the willingness of an individual to request compensation may depend on the current economic climate within that country.

Health surveillance schemes have multiple roles, including serving as an early warning system of new hazards and tracking progress towards goals; but even when supported by legislation, they are rarely comprehensive in coverage. This is especially true of the diverse combinations of exposures, events and disease that underlie occupational ill-health. Here and elsewhere ${ }^{10}$ we have argued that this does not rule out reliable estimation of change in incidence if time-related biases are well understood. As noted earlier, Eurostat has ceased to collect OD statistics because of lack of harmonisation of diagnoses and reporting methods. We believe that important questions can be answered while allowing individuality, and to some extent we have achieved Eurostat aims. ${ }^{3}$

Surveillance data may also be used to formally evaluate the impact of interventions (as in before and after or interrupted time series studies ${ }^{36}$ but again the biases need to be understood. Our data describe the secular trends in OD in Europe during a period when improving working conditions was given a high priority but our data and methods could also be used for formal evaluation of the impact of interventions. For example, in the 
UK, these data were used to show a positive impact of the EU chromate directive. ${ }^{37}$ Future work using these Europe-wide data might provide insight into the impact of the EU vibration directive $^{38}$ on vibration-related OD.

The diversity of occupational surveillance systems described may be of interest to readers in other countries who are considering the development of new systems. A fuller analysis of the strengths and weaknesses of the systems-for trends analysis and as early warning systems-might be useful ${ }^{39}$ but, in practice, there will be local constraints (eg, economic) on what can be achieved and implementing the 'best' may not be achievable. We have shown that a more flexible approach-allowing each country to provide data that is relevant to their individual occupational healthcare systems and sector profiles-does not rule out international epidemiological studies. Two of the key strategic objectives of the EU Strategic Framework on Health and Safety at Work $2014-2020^{40}$ are to improve statistical data collection and simplify existing EU legislation; we believe that this paper goes some way towards the first objective and may inform the second objective.

\section{Author affiliations}

${ }^{1}$ Centre for Occupational and Environmental Health, University of Manchester, Manchester, UK

${ }^{2}$ NIHR Greater Manchester Primary Care Patient Safety Translational Research Centre, University of Manchester, Manchester, UK

${ }^{3}$ Centre for Biostatistics, University of Manchester, Manchester, UK

${ }^{4}$ Coronel Institute of Occupational Health, Academic Medical Center, University of Amsterdam, Amsterdam, The Netherlands

${ }^{5}$ Inserm U954, Vandoeuvre Les Nancy, France

${ }^{6}$ Occupational Diseases Department, University Hospital, Nancy, France

${ }^{7}$ Centre for Occupational Health, National Institute of Public Health, Prague, Czech Republic

${ }^{8}$ Department of Occupational Medicine, 1st Faculty of Medicine, Charles University, Prague, Czech Republic

${ }^{9}$ Istituto Nazionale Assicurazione contro gli Infortuni sul Lavoro (INAIL) Research, Rome, Italy

${ }^{10}$ Finnish Institute of Occupational Health, Tampere, Finland

${ }^{11}$ School of Occupational Medicine, University of Zaragoza, Zaragoza, Spain

${ }^{12}$ Département Santé Travail, Institut de veille sanitaire, Saint Maurice, France

${ }^{13}$ Department of Public Health and Primary Care, KU Leuven, Leuven, Belgium

${ }^{14}$ IDEWE, Heverlee, Belgium

${ }^{15}$ Department of Occupational Medicine \& Department of Actuarial Science, Suva

(Swiss National Accident Insurance Fund), Lucerne, Switzerland

${ }^{16}$ Medical Faculty, University of Basel, Basel, Switzerland

${ }^{17}$ Caisse nationale de l'assurance maladie des travailleurs salariés, Paris, France

${ }^{18}$ National Institute of Occupational Health, Oslo, Norway

${ }^{19}$ Département de Médecine et Santé au travail, Pôle Santé publique, CHU Grenoble, Grenoble, France

${ }^{20}$ Observatoire régional de santé île-de-France, ORS Île-de-France, Paris, France

${ }^{21}$ Occupational Diseases Department, University Hospital of Centre of Paris COCHIN, AP-HP, Paris, France

${ }^{22}$ Paris Descartes University, Sorbonne Paris Cité, EA 4064, Laboratoire Santé Publique et Environnement, Paris, France

${ }^{23}$ Agence Nationale de Sécurité Sanitaire (ANSES), Maisons-Alfort, France

${ }^{24}$ Norwegian Labour Inspection Authority, Trondheim, Norway

${ }^{25}$ Swiss Central Office for Statistics in Accident Insurance-SSUV, Lucerne, Switzerland

${ }^{26}$ Department of Biomedical and Clinical Sciences, University of Milano, Milano, Italy

${ }^{27}$ Department of Medical and Surgical Sciences, University of Bologna, Bologna, Italy

Acknowledgements The authors thank the to THOR reporters, the RNV3P group, MCP reporting physicians, reporters to the Norwegian Registry of Occupational Department patients, Dutch reporting physicians and reporters to Malprof.

Collaborators The following collaborators contributed substantially: Melanie Carder (University of Manchester), Monique HW Frings-Dresen, Fred Moejes, Astrid Schop (University of Amsterdam), Fenclová Zdenka (Charles University, Prague), Antonella Cuteri (INAIL, Rome), Mª Jesús Bone, Ismael Diana (University of Zaragoza).

Contributors SJS collated the data, undertook the analysis and made the first draft of the manuscript. RM developed the statistical methods and contributed substantially to the first draft of the manuscript. All other authors designed the study, contributed data, contributed to interpretation of the data, provided background information and commented on the manuscript.

Funding The EU-COST action IS1002 provided funding for meetings of the authors. THOR is partly funded by the UK HSE, RNV3P is partly funded by ANSES and CNAM, MCP is funded by the InVS, MalProf is funded by INAIL, the Norwegian data collection is funded by the Ministry of Labour and Social Affairs and the Dutch registries are funded by the Ministry of Social Affairs and Employment. Any opinions and conclusions expressed herein are solely those of the authors and not of the funding body.

\section{Competing interests None.}

Disclaimer This abstract has been translated and adapted from the original English-language content. Translated content is provided on an "as is" basis. Translation accuracy or reliability is not guaranteed or implied. BMJ is not responsible for any errors and omissions arising from translation to the fullest extent permitted by law, BMJ shall not incur any liability, including without limitation, liability for damages, arising from the translated text.

Ethics approval All authors obtained ethical review and approval if required.

Provenance and peer review Not commissioned; externally peer reviewed.

Data sharing statement Data requests should be made in writing to the author representing each data set. Alternatively, the corresponding author will forward requests to the appropriate author.

\section{REFERENCES}

1 The Council of the European Union. A new Community strategy on health and safety at work (2007-2012). Official Journal of the European Union 2007/C 145/ 01. http://eur-lex.europa.eu/LexUriServ/LexUriServ.do?uri=0J: C:2007:145:0001:0004:EN:PDF (accessed 8 Aug 2014).

2 Smulders P. A review and analysis of a selection of OSH monitoring systems. Report to the European Agency for Safety and Health at Work. Luxembourg: Office for Official Publications of the European Communities; 2003 ISBN 92-9191-046-5. https://osha.europa.eu/en/publications/reports/406/view (accessed 8 Aug 2014).

3 EU Commission staff working document. Evaluation of the European Strategy 2007-2012 on health and safety at work 2013. http://ec.europa.eu/social/ BlobServlet?docld=10012\&langld=en (accessed 8 Aug 2014).

4 Statistics Explained, your guide to European statistics. http://epp.eurostat.ec.europa. eu/statistics_explained/index.php/Main_Page (accessed 8 Aug 2014).

5 European Union. European Statistics on Accidents at Work (ESAW) Summary methodology. Publications Office of the European Union; 2012.EU Bookshop, http:/ bookshop.europa.eu): http://epp.eurostat.ec.europa.eu/cache/ITY_OFFPUB/ KS-RA-12-002/EN/KS-RA-12-002-EN.PDF (accessed 8 Aug 2014).

6 Dupre D, Karjalainen A, Dyreborg J; and the Members of the Working Group and the Task Force EODS. European Occupational Diseases Statistics (EODS) Phase 1 Methodology. European Commission 2000, Doc. OS/E3/HSW/2000/1081. Eurostat secretariat-Unit E3, Bech Building D2/727-5, rue Alphonse Weicker-L-2721 Luxembourg http://ec.europa.eu/social/BlobServlet?docld=3153\&langld=en (accessed 8 Aug 2014).

7 Eurostat. Persons reporting one or more work-related health problems in the past 12 months, by sex, age and education_\%. Eurostat; Code: hsw_pb1. http:// appsso.eurostat.ec.europa.eu/nui/show.do?dataset=hsw_pb1\&lang=en (accessed 8 Aug 2014).

8 Paris C, Ngatchou-Wandji J, Luc A, et al. Work-related asthma in France: recent trends for the period 2001-2009. Occup Environ Med 2012;69:391-7.

9 Vandenplas 0, Lantin AC, Alpaos VD, et al. Time trends in occupational asthma in Belgium. Respir Med 2011;105:1364-72.

10 McNamee R, Carder M, Chen Y, et al. Measurement of trends in incidence of work-related skin and respiratory diseases, UK 1996-2005. Occup Environ Med 2008;65:808-814. http://www.population-health.manchester.ac.uk/epidemiology/ COEH/research/thor. (accessed 8 Aug 2014).

11 MODERNET, a network for development of new techniques for discovering trends in occupational and work-related diseases and tracing new and emerging risks. ISCH COST Action IS1002. http://www.costmodernet.org http://www.cost.eu/domains_ actions/isch/Actions/IS1002/(glossary)/off (accessed 8 Aug 2014).

12 European Agency for Health and Safety at Work: European directives. https://osha. europa.eu/en/legislation/directives/directives-intro (accessed 8 Aug 2014).

13 European legal requirements relating to work-related MSDs. https://osha.europa.eu/ en/topics/msds/legislation_html (accessed 8 Aug 2014).

14 Samant Y, Parker D, Wergeland E, et al. The Norwegian Labour Inspectorate's Registry for Work-Related Diseases: data from 2006. Int J Occup Environ Health 2008; 14:272-9.

15 Valenty $M$, Homère J, Mevel $M$, et al. (2012) Surveillance Programme of Work-related Diseases (WRD) in France. Saf Health Work 2012;3:67-70. http:// www.invs.sante.fr/Dossiers-thematiques/Travail-et-sante/Maladies-a-caractereprofessionnel (accessed 8 Aug 2014). 
16 van der Laan G. Report on the current situation in relation to occupational diseases' system in EU Member States and EFTA/EEA countries, in particular relative to Commission Recommendation 2003/670/EC concerning the European Schedule of Occupational Diseases and gathering of data on relevant related aspects 2012. http://www.uems-occupationalmedicine.org/sites/default/files/download_pages/1/ final_report_ods_study.pdf (accessed 8 Aug 2014).

17 Bonneterre $\bar{V}$, Faisandier L, Bicout D, et al. Programmed health surveillance and detection of emerging diseases in occupational health: contribution of the French national occupational disease surveillance and prevention network (RNV3P). Occup Environ Med 2010;67:178-86.

18 The Malattie Professionali surveillance system (MalProf). http://www.ispesl.it/ statistiche/index_mp.asp (accessed 8 Aug 2014).

19 Molen HFvd, Kuijer PPFM, Smits PBA, et al. Annual incidence of occupational diseases in economic sectors in the Netherlands. Occup Environ Med 2012;69:519-21.

20 National Institute of Occupational Health ( $\mathrm{NIOH})$. http://www.stami.no/start-page (accessed 11 Aug 2014)

21 Caisse Nationale de l'Assurance Maladie des Travailleurs Salariés (CNAMTS). http:/l www.ameli.fr/l-assurance-maladie/connaitre-I-assurance-maladie/ getting-informed-about-health-insurance/health-insurance/introduction-of-cnamts. php (accessed 8 Aug 2014).

22 Istituto nazionale per l'assicurazione contro gli infortuni sul lavoro (INAIL). http://www.inail.it/internet_web/appmanager/internet/home (accessed 8 Aug 2014).

23 Belgium Compensation Fund for Occupational Diseases. http://www.fmp-fbz.fgov.be (accessed 8 Aug 2014).

24 Occupational Diseases in The Czech Republic. http://www.szu.cz/uploads/english/ document/Occupational_diseases_in_the_CZ_1996_2012.pdf (accessed 8 Aug 2014).

25 Finnish Register of Occupational Diseases (FROD). Occupational diseases in Finland in 2002: New cases of occupational diseases reported to the Finnish Register of Occupational Diseases. http://www.ttl.fi/en/publications/Electronic_publications/ Documents/Occupational_diseases_2002.pdf (accessed 8 Aug 2014) http://www.tvl. fi/en/Claims/Compensated-incidents/Occupational-disease-Definition-of-anoccupational-disease. Accessed 8 Aug 2014. http://www.ttl.fi/fi/verkkokirjat/ ammattitaudit/Sivut/default.aspx (accessed 8 Aug 2014)

26 Occupational Diseases Registry of the Social Security System (Seguridad Social). http://www.seg-social.es/Internet_1/index.htm (accessed 8 Aug 2014).

27 Central Office for Statistics in Accident Insurance. Statistik der Unfallversicherung UVG. http://www.unfallstatistik.ch (accessed 8 Aug 2014).

28 UK Health and Safety Executive. IIDB - Industrial Injuries Disablement Benefit Scheme. http://www.hse.gov.uk/statistics/tables/index.htm\#iidb (accessed 8 Aug 2014).

29 Council Directive 98/24/EC of 7 April 1998 on the protection of the health and safety of workers from the risks related to chemical agents at work (fourteenth individual Directive within the meaning of Article 16(1) of Directive 89/391/EEC). Official Journal of the European Union 1998 L31:11-23. http://eur-lex.europa.eu/
legal-content/EN/TXT/PDF/?uri=CELEX:31998L0024\&from=EN (accessed 9 Aug 2014).

30 Commission Directive 2009/161/EU of 17 December 2009 establishing a third list of indicative occupational exposure limit values in implementation of Council Directive 98/24/EC and amending Commission Directive 2000/39/EC. Official Journal of the European Union 1998 L338:87-89. http://eur-lex.europa.eu/legal-content/EN/TXT/ PDF/?uri=CELEX:32009L0161\&from=EN (accessed 9 Aug 2014).

31 Directive 2003/10/EC of the European Parliament and of the Council of 6 February 2003 on the minimum health and safety requirements regarding the exposure of workers to the risks arising from physical agents (noise). Official Journal of the European Union 2003 L42:38-44. http://eur-lex.europa.eu/legal-content/EN/TXT/ PDF/?uri=CELEX:32003L0010\&from=EN (accessed 9 Aug 2014).

32 Prevencion de riesgos laborales. EL_RUIDO._El_mayor_contaminante_laboral_y_ urbano. http://www.ccoo-euskadi.net/comunes/recursos/9/pub52032_EL_RUIDO. _El_mayor_contaminante_laboral_y_urbano.pdf (accessed 8 Aug 2014).

33 Ministere du Travail de la Solidarite et de la Function Publique. Plan Santé au Travail 2005-2009. http://travail-emploi.gouv.fr/IMG/pdf/PST.pdf (accessed 8 Aug 2014).

34 Ministere du Travail de la Solidarite et de la Function Publique. Lancement De La Campagne TMS 2010. http://www.travailler-mieux.gouv.fr/IMG/pdf/1er_avril_ 2010_-_DP_TMS_DEF.pdf (accessed 8 Aug 2014)

35 Swiss Central Office for Statistics in Accident Insurance http://www.suva.ch/medien-suva/ medien-suva/medienmitteilungen-suva/2011/40-jahre-audiomobileviermal-weniger-gehoerschaeden/medienmitteilung-detail-suva.htm. (accessed 8 Aug 2014)

36 van der Molen HF, Lehtola MM, Lappalainen J, et al. Interventions to prevent injuries in construction workers. Cochrane Database Syst Rev 2012;12:CD006251. http://summaries.cochrane.org/CD006251/INJ_interventions-to-reduce-injuriesin-construction-workers\#sthash.B3rVNuNO.dpuf (accessed 11 Aug 2014).

37 Stocks SJ, Turner S, McNamee R, et al. Has European Union legislation to reduce exposure to chromate in cement been effective in reducing the incidence of allergic contact dermatitis attributed to chromate in the UK? Occup Environ Med 2012;69:150-2

38 Directive 2002/44/ec of the European Parliament and of the Council of 25 June 2002 on the minimum health and safety requirements regarding the exposure of workers to the risks arising from physical agents (vibration) (sixteenth individual Directive within the meaning of Article 16(1) of Directive 89/391/EEC). Official Journal of the European Union 2002 L177:13-19. http://eur-lex.europa.eu/resource. html?uri=cellar:546a09c0-3ad1-4c07-bcd5-9c3dae6b1668.0004.02/DOC 1\&format=PDF (accessed 8 Aug 2014).

39 Spreeuwers D, de Boer AG, Verbeek JH, et al. Characteristics of national registries for occupational diseases: international development and validation of an audit tool (ODIT). BMC Health Serv Res 2009;9:194.

40 Communication from the Commission to the European Parliament, the Council, the European Economic and Social Committee and the Committee of the Regions on an EU Strategic Framework on Health and Safety at Work 2014-2020. 2014. http:// eur-lex.europa.eu/legal-content/EN/TXT/PDF/?uri=CELEX:52014DC0332\&from=EN (accessed 11 Aug 2014). 